\title{
Respon Morfo-fisiologi Empat Genotipe Cabai Rawit \\ (Capsicum frutescens L.) terhadap Cekaman Salinitas
}

\section{Morpho-Physiological Responses of Four Cayenne Pepper Genotypes (Capsicum frutescens L.) to Salinity Stress}

\author{
Baiq Arriyadul Badi'ah ${ }^{1}$, Sobir ${ }^{2 *}$, Muhammad Syukur ${ }^{2}$, dan Yudiwanti Wahyu Endro Kusumo ${ }^{2}$ \\ 'Program Studi Pemuliaan dan Bioteknologi Tanaman, Sekolah Pascasarjana, Institut Pertanian Bogor \\ ${ }^{2}$ Departemen Agronomi dan Hortikultura, Fakultas Pertanian, Institut Pertanian Bogor \\ (IPB University), Jl. Meranti, Kampus IPB Darmaga, Bogor 16680, Indonesia
}

Diterima 10 Agustus 2021/Disetujui 27 Agustus 2021

\begin{abstract}
The responses of cayenne pepper to salinity need to be elucidated for developing saline tolerant varieties. The study aimed to reveal the morphological and physiological responses of four cayenne pepper genotypes under salinity stress conditions. The research was conducted at the Tajur 2 experimental station of IPB University, Bogor, Indonesia, from October 2019 to March 2020. A two-factor randomized complete block design with five blocks as replications was used in this experiment. The first factor is the genotype of cayenne pepper (Sigantung, CR10, CSR1, and CRK1) and the second factor is salinity level $(0-1,2-4,5-7$, and $8-10 \mathrm{mS} \mathrm{cm}-1)$. The results indicated that the salinity significantly affected the morphological and physiological traits of cayenne pepper plants. Salinity $8-10 \mathrm{mS} \mathrm{cm} \mathrm{m}^{-1}$ on morphological traits caused the highest decrease in the number of flowers $(74.65 \%)$, number of leaves $(71.23 \%)$, fruit weight $(58.48 \%)$, and root length $(49.81 \%)$. In addition, a concentration of 8-10 $\mathrm{mS} \mathrm{cm}^{-1}$ also caused the highest decrease in physiological traits. The highest effect of the treatment occurred in stomata conductance (29.37\%), transpiration rate (26.47\%), intercellular $\mathrm{CO}_{2}$ concentration (21.83\%), and chlorophyll index (20.19\%). Based on the average value of the stress sensitivity index (ISC), the Sigantung (1.2) and CSR1 (1.0) genotypes were categorized as salinity sensitive (ISC >1.0). On the other hand, CR10 and CRK1 had an average ISC value of 0.8 , so they were categorized as the moderate tolerance to salinity $(0.5<I S C<0.1)$.
\end{abstract}

Keywords: stomatal conductance, intercellular $\mathrm{CO}_{2}$ concentration, stress sensitivity index, root length

\section{ABSTRAK}

Penelitian tentang respon cabai rawit terhadap salinitas perlu dilakukan untuk pengembangan varietas yang toleran salinitas. Penelitian ini bertujuan untuk mengetahui respon morfologi dan fisiologi empat genotipe cabai rawit pada kondisi cekaman salinitas. Penelitian dilakukan di kebun percobaan Tajur 2 IPB Bogor pada bulan Oktober 2019-Maret 2020. Rancangan kelompok lengkap teracak dua faktor dengan lima kelompok sebagai ulangan digunakan dalam percobaan ini. Faktor pertama yaitu genotipe cabai rawit (Sigantung, CR10, CSR1, dan CRK1) dan faktor kedua adalah taraf salinitas (01, 2-4, 5-7, dan 8-10 $\mathrm{mS} \mathrm{cm}^{-1}$. Hasil yang diperoleh menunjukkan bahwa salinitas secara signifikan berpengaruh terhadap peubah morfologi dan fisiologi tanaman cabai rawit. Salinitas $8-10 \mathrm{mS} \mathrm{cm}{ }^{-1}$ pada peubah morfologi menyebabkan penurunan hasil tertinggi pada jumlah bunga (74.65\%), jumlah daun (71.23\%), bobot buah (58.48\%), dan panjang akar (49.81\%). Selain itu, pada konsentrasi $8-10 \mathrm{mS} \mathrm{cm} \mathrm{cm}^{-1}$ juga menyebabkan penurunan hasil tertinggi pada peubah fisiologi. Penurunan hasil tertinggi terjadi pada konduktansi stomata (29.37\%), laju transpirasi (26.47\%), konsentrasi $\mathrm{CO}_{2}$ interseluler (21.83\%), dan indeks klorofil (20.19\%). Berdasarkan nilai rata-rata indeks sensitivitas cekaman (ISC), genotipe Sigantung (1.2) dan CSR1 (1.0) termasuk katagori peka salinitas (ISC $\geq 1.0$ ). Akan tetapi, CR10 dan CRK1 memiliki nilai rata-rata ISC sebesar 0.8, sehingga termasuk ke dalam katagori moderat toleran salinitas $(0.5<I S C<0.1)$.

Kata kunci: indeks sensitivitas cekaman (ISC), konduktansi stomata, konsentrasi $\mathrm{CO}_{2}$ interseluler, panjang akar

\footnotetext{
* Penulis untuk korespondensi. e-mail: rsobir@yahoo.com
} 


\section{PENDAHULUAN}

Kondisi geografis Indonesia menyebabkan rentannya daerah-daerah pesisir terhadap dampak intrusi air laut (Purnama, 2019). Menurut Suhartono et al. (2015), intrusi air laut di Indonesia mengalami peningkatan sekitar $0.58 \mathrm{~km}^{2}$ per tahunnya. Pemanasan global dan aktivitas antropogenik juga berperan dalam mempercepat proses intrusi air laut (Safi et al., 2018). Intrusi air laut ke daratan akan menyebabkan tanah memiliki kadar garam yang tinggi, sehingga tanah menjadi salin. Tanah salin juga dapat terjadi akibat bahan induk tanah yang mengandung garam dan tingginya penguapan dibandingkan presipitasi. Hal ini menyebabkan tanah salin tidak hanya dijumpai di pesisir pantai (Rachman et al., 2018).

Sopandie (2013) menyatakan bahwa kadar natrium 8$15 \%$, akan mengakibatkan pertumbuhan dan perkembangan tanaman terhambat. Petani di pesisir pantai utara (Pantura), telah merasakan dampak lahan salin di Indonesia sejak tahun 2017 (Sembiring et al., 2020). Selain di Pulau Jawa, dampak lahan salin juga terjadi di Aceh (Muhni et al., 2018; Marohn et al., 2012), Riau (Putra et al., 2019), dan Makasar (Ramli et al., 2019). Luas lahan salin akan terus meningkat dan membutuhkan perhatian lebih, sehingga perlu dilakukan antisipasi terhadap hal tersebut. Optimalisasi pemanfaatan tanah salin dapat dilakukan dengan menggunakan varietas yang toleran terhadap tanah salin. Akan tetapi, merakit varietas tanaman cabai rawit yang toleran terhadap salinitas, membutuhkan berbagai informasi mengenai respon tanaman terhadap cekaman salinitas.

Penelitian mengenai respon tanaman terhadap salinitas telah banyak dilakukan pada tanaman hortikultura dari famili Solanaceae, seperti pada kentang (Ahmed et al., 2020), terung (Sobir, et al., 2018), tomat (Martínez et al., 2020), paprika (Giorio et al., 2020), dan cabai (Mustafa et al., 2019). Akan tetapi, penelitian mengenai salinitas pada cabai berfokus pada spesies Capsicum annum L. sedangkan respon C. frutescens terhadap salinitas masih banyak berfokus pada morfologi. Oleh karena itu, penelitian ini bertujuan untuk memeroleh informasi ilmiah mengenai respon morfologi maupun fisiologi empat genotipe tanaman cabai rawit terhadap berbagai taraf salinitas yang diberikan.

\section{BAHAN DAN METODE}

\section{Bahan Genetik}

Percobaan dilakukan di Rumah Kaca Kebun Percobaan Tajur IPB Bogor, bulan Oktober 2019 sampai dengan Maret 2020. Materi genetik yang digunakan adalah empat genotipe cabai rawit (Capsicum frutescens L.), yang terdiri atas: tiga genotipe koleksi Pusat Kajian Hortikultura Tropika (CR10, CSR1, dan CRK1) dan satu varietas komersial (Sigantung).

\section{Desain Percobaan dan Perlakuan Cekaman Salinitas}

Rancangan kelompok lengkap teracak (RKLT) dengan dua faktor dan kelompok sebagai ulangan yang diulang sebanyak lima kali digunakan dalam percobaan ini. Faktor pertama adalah genotipe cabai rawit dan faktor kedua adalah taraf salinitas. Genotipe cabai rawit yang digunakan adalah Sigantung, CR10, CSR1, dan CSK1, sedangkan taraf salinitas yang digunakan adalah $0-1,2-4,5-7$, dan 8$10 \mathrm{mS} \mathrm{cm}{ }^{-1}$. Taraf $0-1 \mathrm{mS} \mathrm{cm}^{-1}$ digunakan sebagai kontrol, tanpa penambahan $\mathrm{NaCl}$. Taraf 2-4, 5-7, dan 8-10 mS cm ${ }^{1}$ diperoleh dengan masing-masing menambahkan 1.5, 3.0, dan $4.5 \mathrm{~g} \mathrm{~L}^{-1} \mathrm{NaCl}$. Perlakuan salinitas diberikan dengan cara penyiraman menggunakan larutan $\mathrm{NaCl}$ sesuai taraf salinitas yang diujikan. Pemberian larutan $\mathrm{NaCl}$ dilakukan saat tanaman berumur 3-27 MST.

Media semai dan media tanam yang digunakan berupa tanah, pupuk kandang, dan sekam dengan perbandingan 1:1:1 (v/v/v). Semaian dipindahkan ke polibag ukuran $40 \mathrm{~cm}$ x 40 cm setelah memiliki 3-4 helai daun. Pemeliharaan tanaman dilakukan dengan penyulaman (2 MST), pemasangan ajir (4 MST), pengendalian gulma dan tunas air, pemberian pupuk $10 \mathrm{~g} \mathrm{~L}^{-1}$ NPK mutiara (15-15-15) dilakukan dengan pengocoran seriap satu bulan sekali, pengendalian hama dan penyakit dilakukan dengan cara penyemprotan pestisida secara intensif (insektisida: profenofos $500 \mathrm{~g} \mathrm{~L}^{-1}$, abamektin $0.5 \mathrm{~mL} \mathrm{~L}^{-1}$, deltametri $25 \mathrm{~g} \mathrm{~L}^{-1}$; bakterisida: streptomisin sulfat $20 \%$; fungisida: mankozeb $80 \%$ ).

\section{Parameter Pengamatan}

Pengamatan morfologi yang diamati mengacu pada Descriptor for Capsicum (IPGRI, 1995). Peubah morfologi yang diamati adalah panjang akar $(\mathrm{cm})$, tinggi tanaman (cm), lebar tajuk $(\mathrm{cm})$, jumlah daun (helai), jumlah bunga (bunga), jumlah buah (buah), dan bobot buah (g). Peubah panjang akar diukur dari bagian pangkal akar sampai ujung akar terpanjang. Pengamatan dilakukan pada umur $24 \mathrm{MST}$, kecuali pada panjang akar dan lebar tajuk (27 MST). Bobot buah cabai rawit yang digunakan adalah bobot buah pada panen kedua.

Pengamatan fisiologi dilakukan pada daun kelima dari pucuk di umur $18 \mathrm{MST}$, meliputi konsentrasi $\mathrm{CO}_{2}$ interseluler, laju transpirasi, laju fotosintesis, dan konduktansi stomata. Pengukuran peubah-peubah tersebut dilakukan dengan menggunakan Portable Photosynthesis System (LI6400, LICOR, Inc., Lincoln, NE, USA). Analisis indeks klorofil dilakukan menggunakan SPAD (atLeaf). Analisis Kandungan Air Relatif dilakukan berdasarkan metode Smart dan Bingham (1974), dimana BS = berat segar, BJ = berat kering, $\mathrm{BK}=$ berat kering.

$$
\mathrm{KAR}=\frac{(\mathrm{BS}-\mathrm{BK})}{(\mathrm{BJ}-\mathrm{BK})} \times 100 \%
$$

Analisis Data

Analisis ragam $(\alpha=5 \%)$ dan uji lanjut duncan's multiple range test (DMRT) dianalisis menggunakan software SAS 9.0, dengan $\alpha=5 \%$. Respon cabai rawit terhadap salinitas, dikelompokkan berdasarkan nilai indeks sensitivitas cekaman (ISC) berdasarkan rumus Fisher dan Maurer (1978), sebagai berikut:

$$
\text { ISC }=(1-\mathrm{Y} / \mathrm{Yp}) /(1-\mathrm{X} / \mathrm{Xp})
$$


Variabel Y adalah nilai peubah untuk tiap genotipe pada kondisi salinitas. Variabel Yp adalah nilai peubah untuk tiap genotipe pada kondisi normal. Variabel $\mathrm{X}$ adalah nilai rata-rata respon genotipe terhadap karakter pengamatan pada kondisi salinitas. Variabel Xp adalah nilai rata-rata respon genotipe terhadap karakter pengamatan pada kondisi normal. Jika nilai ISC $\leq 0.5$ maka genotipe tersebut toleran terhadap salinitas, jika $0.5<$ ISC $\leq 1.0$ maka genotipe tersebut moderat toleran terhadap salinitas, dan jika ISC $>1.0$ maka genotipe tersebut peka terhadap salinitas

\section{HASIL DAN PEMBAHASAN}

Hasil pengamatan menunjukkan bahwa semua peubah yang diamati memiliki perbedaan yang sangat nyata terhadap masing-masing taraf salinitas. Selain itu, terjadi interaksi antara genotipe dan taraf salinitas yang diberikan pada peubah morfologi.

\section{Respon Morfologi Tanaman Cabai Rawit terhadap Cekaman} Salinitas

Tabel 1 menunjukkan bahwa semakin tinggi taraf salinitas yang diberikan akan menyebabkan penurunan nilai rata-rata pada semua peubah morfologi yang diamati. Nilai rata-rata genotipe CRK1 memiliki nilai tertinggi pada peubah panjang akar, tinggi tanaman, lebar tajuk, dan jumlah buah, jika dibandingkan dengan tiga genotipe lainnya. Akan tetapi, untuk peubah bobot buah, nilai rata-rata tertinggi terdapat pada genotipe Sigantung. Hal ini dikarenakan ukuran buah Sigantung lebih besar dibandingkan genotipe CR10, CSR1, dan CRK1. Adanya perbedaan respon pada masing-masing genotipe diduga akibat perbedaan genetik masing-masing tanaman, meskipun masih dalam satu spesies. Selain adanya perbedaan genetik, pengaruh cekaman salinitas juga menyebabkan perbedaan yang signifikan yang mengakibatkan respon masing-masing tanaman berbeda. Aini et al. (2014) mengemukakan bahwa respon tanaman terhadap cekaman salinitas dipengaruhi oleh spesies atau genotipe tanaman.

Berdasarkan Tabel 2, penurunan hasil yang paling tinggi terjadi pada taraf salinitas $8-10 \mathrm{mS} \mathrm{cm}^{-1}$. Taraf salinitas $8-10 \mathrm{mS} \mathrm{cm}{ }^{-1}$ menyebabkan tanaman cabai rawit mengalami penurunan hasil tertinggi pada peubah jumlah bunga (74.65\%), jumlah daun (71.23\%), bobot buah, (58.48\%) dan panjang akar (49.81\%). Penurunan hasil pada peubah jumlah bunga terjadi seiring bertambahnya taraf salinitas yang diberikan. Hal ini diduga terjadi akibat

Tabel 1. Hasil analisis DMRT pada peubah morfologi cabai rawit dengan berbagai taraf salinitas

\begin{tabular}{|c|c|c|c|c|c|c|c|}
\hline \multirow[b]{2}{*}{ Perlakuan } & \multicolumn{7}{|c|}{ Peubah morfologi } \\
\hline & $\begin{array}{c}\text { Panjang } \\
\text { akar } \\
(\mathrm{cm})\end{array}$ & $\begin{array}{c}\text { Tinggi } \\
\text { tanaman } \\
(\mathrm{cm})\end{array}$ & $\begin{array}{l}\text { Lebar } \\
\text { tajuk } \\
(\mathrm{cm})\end{array}$ & $\begin{array}{l}\text { Jumlah } \\
\text { daun }\end{array}$ & $\begin{array}{l}\text { Jumlah } \\
\text { bunga }\end{array}$ & $\begin{array}{l}\text { Jumlah } \\
\text { buah }\end{array}$ & $\begin{array}{c}\text { Bobot } \\
\text { buah } \\
(\mathrm{g})\end{array}$ \\
\hline \multicolumn{8}{|l|}{ Genotipe (G) } \\
\hline Sigantung & $34.38 b$ & $119.23 b$ & $65.22 \mathrm{c}$ & $73.6 \mathrm{c}$ & $28.4 d$ & $57.9 \mathrm{~d}$ & $78.43 \mathrm{a}$ \\
\hline CR10 & $34.01 b$ & $100.15 d$ & $58.43 d$ & $79.6 b$ & 79.1a & $68.1 \mathrm{c}$ & $21.67 b$ \\
\hline CSR 1 & $30.94 \mathrm{c}$ & $109.16 \mathrm{c}$ & $73.22 b$ & $95.9 \mathrm{a}$ & $57.8 \mathrm{c}$ & $75.3 b$ & $23.82 b$ \\
\hline CRK 1 & $37.12 \mathrm{a}$ & $125.11 \mathrm{a}$ & $74.37 \mathrm{a}$ & $77.9 b c$ & $65.0 \mathrm{~b}$ & $77.8 \mathrm{a}$ & $21.95 b$ \\
\hline \multicolumn{8}{|c|}{ Taraf Salinitas (S) } \\
\hline $0-1 \mathrm{mS} \mathrm{cm}^{-1}$ & $44.87 \mathrm{a}$ & $132.25 \mathrm{a}$ & $76.60 \mathrm{a}$ & $133.5 \mathrm{a}$ & $85.9 a$ & $85.9 \mathrm{a}$ & $51.27 \mathrm{a}$ \\
\hline $2-4 \mathrm{mS} \mathrm{cm}^{-1}$ & $37.90 \mathrm{~b}$ & $120.01 b$ & $72.01 \mathrm{~b}$ & $102.9 b$ & $78.1 \mathrm{~b}$ & $78.4 \mathrm{~b}$ & $40.58 b$ \\
\hline $5-7 \mathrm{mS} \mathrm{cm}^{-1}$ & $31.61 \mathrm{c}$ & $104.68 \mathrm{c}$ & $65.02 \mathrm{c}$ & $56.5 \mathrm{c}$ & $45.6 \mathrm{c}$ & $62.8 \mathrm{c}$ & $32.10 \mathrm{c}$ \\
\hline $8-10 \mathrm{mS} \mathrm{cm}^{-1}$ & $22.07 \mathrm{~d}$ & $96.70 \mathrm{~d}$ & $57.61 d$ & $38.0 \mathrm{~d}$ & $20.7 d$ & $51.9 \mathrm{~d}$ & $21.93 \mathrm{~d}$ \\
\hline
\end{tabular}

Keterangan: Angka yang diikuti huruf yang sama pada kolom yang sama tidak berbeda nyata berdasarkan DMRT pada taraf $\alpha=5 \%$

Tabel 2. Persentase penurunan hasil cabai rawit pada masing-masing peubah morfologi yang diamati

\begin{tabular}{lccccccc}
\hline $\begin{array}{l}\text { Salinitas } \\
\left(\mathrm{mS} \mathrm{cm}^{-1}\right)\end{array}$ & $\begin{array}{c}\text { Panjang akar } \\
(\mathrm{cm})\end{array}$ & $\begin{array}{c}\text { Tinggi tanaman } \\
(\mathrm{cm})\end{array}$ & $\begin{array}{c}\text { Lebar tajuk } \\
(\mathrm{cm})\end{array}$ & $\begin{array}{c}\text { Jumlah } \\
\text { daun }\end{array}$ & $\begin{array}{c}\text { Jumlah } \\
\text { bunga }\end{array}$ & $\begin{array}{c}\text { Jumlah } \\
\text { buah }\end{array}$ & $\begin{array}{c}\text { Bobot buah } \\
(\mathrm{g})\end{array}$ \\
\hline $2-4$ & $14.53 \mathrm{c}$ & $8.90 \mathrm{c}$ & $6.03 \mathrm{c}$ & $22.8 \mathrm{c}$ & $11.6 \mathrm{c}$ & $9.1 \mathrm{c}$ & $20.60 \mathrm{c}$ \\
$5-7$ & $28.57 \mathrm{~b}$ & $20.94 \mathrm{~b}$ & $15.52 \mathrm{~b}$ & $60.2 \mathrm{~b}$ & $51.6 \mathrm{~b}$ & $26.9 \mathrm{~b}$ & $38.99 \mathrm{~b}$ \\
$8-10$ & $49.81 \mathrm{a}$ & $27.06 \mathrm{a}$ & $25.04 \mathrm{a}$ & $71.2 \mathrm{a}$ & $74.7 \mathrm{a}$ & $39.7 \mathrm{a}$ & $58.48 \mathrm{a}$ \\
\hline
\end{tabular}

Keterangan: Angka yang diikuti huruf yang sama pada kolom yang sama tidak berbeda nyata berdasarkan DMRT pada taraf $\alpha=5 \%$ 
semakin tinggi level salinitas yang diberikan menyebabkan waktu berbunga semakin lama. Hasil penelitian ini sesuai dengan penelitian Julien et al. (2019) yang menunjukkan bahwa pada cabai rawit (C. frutescens) terjadi penundaan waktu berbunga yang semakin lama, seiring meningkatnya level salinitas. Penelitian Balasankar et al. (2017) pada tanaman cabai (Capsicum annum), menunjukkan bahwa rata-rata bobot buah, jumlah buah, panjang dan lebar buah cabai menurun seiring meningkatnya kadar salinitas yang diberikan. Selain itu, pada penelitian Tehseen et al. (2016) pada tanaman cabai paprika, menunjukkan taraf $8 \mathrm{dS} \mathrm{m}^{-1}$ menyebabkan panjang akar, panjang tajuk, dan jumlah daun menurun.

Tabel 3. Pengaruh interaksi antara genotipe dan salinitas terhadap peubah yang diamati pada tanaman cabai rawit $(C$. frutescens)

\begin{tabular}{|c|c|c|c|c|}
\hline \multirow{2}{*}{ Peubah yang diamati } & \multicolumn{4}{|c|}{ Taraf salinitas $\left(\mathrm{mS} \mathrm{cm}^{-1}\right)$} \\
\hline & $0-1 \mathrm{mS} \mathrm{cm}^{-1 *}$ & $2-4 \mathrm{mS} \mathrm{cm}^{-1}$ & $5-7 \mathrm{mS} \mathrm{cm}^{-1}$ & $8-10 \mathrm{mS} \mathrm{cm}^{-1}$ \\
\hline \multicolumn{5}{|l|}{ Panjang akar (cm) } \\
\hline Sigantung & $44.04 \mathrm{ab}$ & $38.16 \mathrm{~cd}$ & $31.76 \mathrm{f}$ & $23.54 \mathrm{~h}$ \\
\hline CR10 & $48.04 \mathrm{a}$ & $37.90 \mathrm{cde}$ & $32.66 \mathrm{ef}$ & $17.44 \mathrm{i}$ \\
\hline CSR1 & $39.10 \mathrm{bc}$ & $33.74 \mathrm{def}$ & $29.00 \mathrm{fg}$ & 21.90hi \\
\hline CRK1 & $48.30 \mathrm{a}$ & $41.78 \mathrm{bc}$ & $33.00 \mathrm{def}$ & $25.38 \mathrm{gh}$ \\
\hline \multicolumn{5}{|l|}{ Tinggi tanaman $(\mathrm{cm})$} \\
\hline Sigantung & $143.56 \mathrm{a}$ & $117.46 \mathrm{e}$ & $108.02 \mathrm{~g}$ & $107.88 \mathrm{~g}$ \\
\hline CR10 & $119.42 d$ & $116.48 \mathrm{e}$ & $85.02 \mathrm{j}$ & $79.66 \mathrm{k}$ \\
\hline CSR1 & $123.54 \mathrm{c}$ & $114.24 f$ & $105.60 \mathrm{~h}$ & $93.24 \mathrm{i}$ \\
\hline CRK1 & $142.48 \mathrm{a}$ & $131.86 \mathrm{~b}$ & $120.08 \mathrm{c}$ & $106.02 \mathrm{~h}$ \\
\hline \multicolumn{5}{|l|}{ Lebar tajuk (cm) } \\
\hline Sigantung & $73.86 \mathrm{~d}$ & $68.28 \mathrm{f}$ & $62.48 \mathrm{~h}$ & $56.24 \mathrm{i}$ \\
\hline CR10 & $69.86 \mathrm{e}$ & $65.34 \mathrm{~g}$ & $51.26 \mathrm{j}$ & $47.26 \mathrm{k}$ \\
\hline CSR1 & $80.56 b$ & $77.34 \mathrm{c}$ & $73.22 \mathrm{~d}$ & $61.74 \mathrm{~h}$ \\
\hline CRK1 & $82.12 \mathrm{a}$ & $77.08 \mathrm{c}$ & $73.10 \mathrm{~d}$ & $65.18 \mathrm{~g}$ \\
\hline \multicolumn{5}{|l|}{ Jumlah daun } \\
\hline Sigantung & $114.20 \mathrm{c}$ & $85.80 \mathrm{e}$ & $56.40 \mathrm{fg}$ & 37.80hi \\
\hline CR10 & $116.20 \mathrm{c}$ & $123.00 \mathrm{bc}$ & 45.20hi & $33.80 \mathrm{i}$ \\
\hline CSR1 & $176.20 \mathrm{a}$ & $101.60 \mathrm{~d}$ & $62.00 \mathrm{f}$ & 43.80hi \\
\hline CRK1 & $127.40 \mathrm{~b}$ & $101.20 \mathrm{~d}$ & $46.40 \mathrm{gh}$ & 36.40hi \\
\hline \multicolumn{5}{|l|}{ Jumlah bunga } \\
\hline Sigantung & $51.20 \mathrm{e}$ & $35.00 \mathrm{~g}$ & $10.80 \mathrm{k}$ & $16.40 \mathrm{j}$ \\
\hline CR10 & $104.60 \mathrm{a}$ & $101.80 \mathrm{a}$ & $96.40 \mathrm{~b}$ & $13.60 \mathrm{kj}$ \\
\hline CSR1 & $91.20 \mathrm{c}$ & $88.00 \mathrm{~d}$ & $30.20 \mathrm{~h}$ & $21.60 \mathrm{i}$ \\
\hline CRK1 & $96.40 \mathrm{~b}$ & $87.40 \mathrm{~d}$ & $45.00 \mathrm{f}$ & $31.00 \mathrm{~h}$ \\
\hline \multicolumn{5}{|l|}{ Jumlah buah } \\
\hline Sigantung & $75.60 \mathrm{e}$ & $63.00 \mathrm{~h}$ & $51.60 \mathrm{j}$ & $41.40 \mathrm{k}$ \\
\hline CR10 & $81.60 \mathrm{~d}$ & $75.20 \mathrm{e}$ & $62.40 \mathrm{~h}$ & $53.00 \mathrm{j}$ \\
\hline CSR1 & $90.80 \mathrm{c}$ & $82.00 \mathrm{~d}$ & $71.20 \mathrm{f}$ & $57.00 \mathrm{i}$ \\
\hline CRK1 & $95.60 \mathrm{a}$ & $93.40 \mathrm{~b}$ & $66.00 \mathrm{~g}$ & $56.20 \mathrm{i}$ \\
\hline \multicolumn{5}{|l|}{ Bobot buah (g) } \\
\hline Sigantung & $105.42 \mathrm{a}$ & $87.16 b$ & $71.87 \mathrm{c}$ & $49.29 \mathrm{~d}$ \\
\hline CR10 & $35.04 \mathrm{e}$ & $23.02 \mathrm{ghi}$ & $18.45 \mathrm{ij}$ & $10.19 \mathrm{k}$ \\
\hline CSR1 & $34.20 \mathrm{e}$ & $26.95 \mathrm{fg}$ & 19.34hij & $14.79 \mathrm{jk}$ \\
\hline CRK1 & $30.42 \mathrm{fe}$ & $25.17 \mathrm{fgh}$ & $18.76 \mathrm{ij}$ & $13.44 \mathrm{jk}$ \\
\hline
\end{tabular}

Keterangan: Angka yang diikuti oleh huruf yang sama pada kolom yang sama pada masing-masing perlakuan menunjukkan tidak berbeda nyata berdasarkan uji DMRT pada taraf $\alpha=5 \%$. $*=$ kontrol 
Tabel 3 menunjukkan adanya interaksi antara genotipe cabai rawit dan taraf salinitas. Interaksi ditandai dengan adanya perbedaan respon masing-masing genotipe cabai rawit dengan taraf salinitas yang diberikan. Genotipe CR10 dan CRK1 memiliki nilai rata-rata yang tidak berbeda nyata pada kontrol (0-1 $\left.\mathrm{mS} \mathrm{cm}^{-1}\right)$, namun pada taraf salinitas 8$10 \mathrm{mS} \mathrm{cm}^{-1}$ terjadi perbedaan yang signifikan. Hal ini juga terjadi pada peubah tinggi tanaman, dimana pada kondisi kontrol perbedaan nilai rata-rata tidak berbeda nyata antara genotipe Sigantung dan CRK1, namun pada taraf 8-10 $\mathrm{mS} \mathrm{cm}^{-1}$ terjadi perbedaan yang nyata. Peubah lebar tajuk, genotipe CRK1 pada kontrol memiliki nilai ratarata tertinggi dibandingkan tiga genotipe lainnya dan tetap berbeda nyata pada taraf salinitas $8-10 \mathrm{mS} \mathrm{cm}^{-1}$. Selanjutnya, pada peubah jumlah bunga dalam kondisi kontrol, genotipe CRK1 memiliki nilai rata-rata tertinggi, tetapi pada taraf salinitas $8-10 \mathrm{mS} \mathrm{cm}^{-1}$ nilai rata-rata genotipe CRK1 lebih kecil dibandingkan tiga genotipe lainnya. Jumlah buah pada genotipe CRK1 berbeda nyata terhadap tiga genotipe lainnya dalam kondisi kontrol, namun pada taraf salinitas 8$10 \mathrm{mS} \mathrm{cm}^{-1}$ nilai rata-rata jumlah buah tidak berbeda nyata terhadap genotipe CR10 dan CSR1. Genotipe Sigantung memiliki nilai rata-rata tertinggi dibandingkan dengan tiga genotipe lainnya pada peubah bobot buah, baik pada kontrol maupun pada taraf salinitas $8-10 \mathrm{mS} \mathrm{cm-1.} \mathrm{El-Hashash}$ and Agwa (2018) menyatakan bahwa ada pengaruh yang signifikan antara variasi genotipe dan cekaman lingkungan yang diberikan.

\section{Respon Fisiologi Tanaman Cabai Rawit terhadap Cekaman Salinitas}

Tabel 4 menunjukkan bahwa ada perbedaan yang signifikan pada konsentrasi $\mathrm{CO}_{2}$ interseluler, laju transpirasi, laju fotosintesis, konduktansi stomata, indeks klorofil, dan kadar air relatif. Peubah konsentrasi $\mathrm{CO}_{2}$ interseluler, indeks klorofil, dan kandungan air relatif, menunjukkan perbedaan yang signifikan pada faktor genotipe. Perbedaan tersebut menunjukkan bahwa masing-masing genotipe cabai rawit memiliki cara tersendiri untuk merespon cekaman salinitas. Selain itu faktor salinitas menunjukkan bahwa seluruh peubah fisiologi yang diamati memiliki penurunan nilai rata-rata yang signifikan, jika dibandingkan dengan kontrol $\left(0-1 \mathrm{mS} \mathrm{cm}^{-1}\right)$.

Berdasarkan Tabel 5, persentase penurunan hasil pada masing-masing peubah fisiologi semakin meningkat seiring dengan bertambahnya taraf salinitas yang diberikan. Penurunan terbesar terjadi pada taraf salinitas $8-10 \mathrm{mS} \mathrm{cm}^{-1}$, dimana penurunan hasil pada masing-masing peubah lebih dari $20 \%$. Peubah fisiologi berupa konduktansi stomata memiliki persentase penurunan hasil mendekati 30\%, yaitu $29.37 \%$, diikuti laju transpirasi (26.47\%), konsentrasi $\mathrm{CO}_{2}$ interseluler $(21.83 \%)$ dan indeks klorofil (20.19\%). Hasil penelitian ini sesuai dengan penelitian Qiu et al. (2018) yang menyatakan bahwa semakin tinggi salinitas, menyebabkan menurunnya laju fotosintesis, laju transpirasi, konduktansi stomata, dan konsentrasi $\mathrm{CO}_{2}$ interseluler pada daun. Selain itu, menurut Kotagiri dan Chaitanya (2017), adanya cekaman salinitas pada tanaman akan menyebabkan ketersediaan air, translokasi, dan penyerapan air terganggu. Cekaman salinitas akan menyebabkan konduktansi stomata menurun, sehingga kadar air dan penyerapan air terganggu. Terganggunya penyerapan air mengakibatkan kadar air relatif menurun, sehingga terhambatnya pemanjangan sel dan terganggunya aktivitas metabolisme.

\section{Indeks Sensitivitas terhadap Cekaman}

Informasi respon tanaman terhadap cekaman salinitas diperlukan untuk mengelompokkan tanaman ke dalam katagori tanaman yang peka, moderat, atau toleran. Indeks sensitivitas cekaman(ISC) ialah metode indeks yang berguna

Tabel 4. Pengaruh genotipe dan cekaman salinitas terhadap peubah fisiologi tanaman cabai rawit pada umur 18 MST

\begin{tabular}{|c|c|c|c|c|c|c|}
\hline \multirow[b]{2}{*}{ Perlakuan } & \multicolumn{6}{|c|}{ Peubah fisiologi } \\
\hline & $\begin{array}{c}\mathrm{CO} \\
\left(\mu \mathrm{mol} \mathrm{CO} \mathrm{mol}^{-1}\right)\end{array}$ & $\begin{array}{c}\mathrm{LF} \\
\left(\mu \mathrm{mol} \mathrm{CO} \mathrm{C}^{-2} \mathrm{~s}^{-1}\right)\end{array}$ & $\begin{array}{c}\mathrm{LT} \\
\left(\mathrm{mmol} \mathrm{H}_{2} \mathrm{O} \mathrm{m}^{-2} \mathrm{~s}^{-1}\right)\end{array}$ & 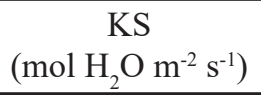 & $\begin{array}{c}\mathrm{IK} \\
\text { (unit) }\end{array}$ & $\begin{array}{l}\mathrm{KR} \\
\text { (unit) }\end{array}$ \\
\hline \multicolumn{7}{|l|}{ Genotipe (G) } \\
\hline Sigantung & $144.99 b$ & 22.02 & 5.26 & 0.183 & $59.27 \mathrm{a}$ & $67.56 b$ \\
\hline CR10 & $178.87 \mathrm{a}$ & 22.73 & 5.24 & 0.179 & $57.21 \mathrm{ab}$ & $70.42 \mathrm{a}$ \\
\hline CSR 1 & $190.21 \mathrm{a}$ & 21.98 & 5.05 & 0.175 & $56.11 \mathrm{cb}$ & $63.44 \mathrm{~b}$ \\
\hline CRK 1 & $175.67 \mathrm{ab}$ & 21.94 & 5.31 & 0.185 & $54.59 \mathrm{c}$ & $67.11 \mathrm{~b}$ \\
\hline \multicolumn{7}{|c|}{ Taraf salinitas (S) } \\
\hline $0-1 \mathrm{mS} \mathrm{cm}^{-1}$ & $200.26 a$ & $24.25 \mathrm{a}$ & $6.01 \mathrm{a}$ & $0.212 \mathrm{a}$ & $63.11 \mathrm{a}$ & $73.07 \mathrm{a}$ \\
\hline $2-4 \mathrm{mS} \mathrm{cm}^{-1}$ & $183.18 b$ & $22.56 b$ & $5.47 b$ & $0.191 b$ & $59.32 b$ & $69.09 \mathrm{~b}$ \\
\hline $5-7 \mathrm{mS} \mathrm{cm}^{-1}$ & $158.77 \mathrm{bc}$ & $21.59 \mathrm{c}$ & $5.02 \mathrm{c}$ & $0.172 \mathrm{c}$ & $54.54 \mathrm{c}$ & $66.05 c$ \\
\hline $8-10 \mathrm{mS} \mathrm{cm}^{-1}$ & $147.54 \mathrm{c}$ & $20.26 \mathrm{~d}$ & $4.36 \mathrm{~d}$ & $0.149 \mathrm{~d}$ & $50.22 \mathrm{~d}$ & $60.32 d$ \\
\hline
\end{tabular}

Keterangan: Angka yang diikuti oleh huruf yang sama pada kolom yang sama tidak berbeda nyata pada uji DMRT 5\%. CO = konsentrasi $\mathrm{CO}_{2}$ intraseluler; $\mathrm{LF}=$ laju fotosintesis; $\mathrm{LT}=$ laju transpirasi; $\mathrm{KS}=$ konduktansi stomata; $\mathrm{IK}=$ Indeks klorofil; $\mathrm{KR}=$ kadar air relatif 
Tabel 5. Persentase penurunan hasil cabai rawit pada masing-masing peubah morfologi yang diamati

\begin{tabular}{lccccrr}
\hline Salinitas & \multicolumn{5}{c}{ Persentase penurunan hasil (\%) } \\
\cline { 2 - 7 }$\left(\mathrm{mS} \mathrm{cm}^{-1}\right)$ & $\mathrm{CO}$ & LF & \multicolumn{1}{c}{ LT } & \multicolumn{1}{c}{ KS } & \multicolumn{1}{c}{ IK } & KR \\
\hline $2-4$ & $4.14 \mathrm{c}$ & $6.86 \mathrm{c}$ & $8.39 \mathrm{c}$ & $9.86 \mathrm{c}$ & $5.76 \mathrm{c}$ & $5.34 \mathrm{c}$ \\
$5-7$ & $17.17 \mathrm{~b}$ & $10.80 \mathrm{~b}$ & $15.62 \mathrm{~b}$ & $18.69 \mathrm{~b}$ & $13.28 \mathrm{~b}$ & $9.60 \mathrm{~b}$ \\
$8-10$ & $21.83 \mathrm{a}$ & $16.26 \mathrm{a}$ & $26.47 \mathrm{a}$ & $29.37 \mathrm{a}$ & $20.19 \mathrm{a}$ & $17.19 \mathrm{a}$ \\
\hline
\end{tabular}

Keterangan: Angka yang diikuti oleh huruf yang sama pada kolom yang sama tidak berbeda nyata pada uji DMRT 5\%. CO = konsentrasi $\mathrm{CO}_{2}$ intraseluler; $\mathrm{LF}=$ laju fotosintesis; $\mathrm{LT}=$ laju transpirasi; $\mathrm{KS}=$ konduktansi stomata; IK = indeks klorofil; $\mathrm{KR}=\mathrm{kadar}$ air relatif

untuk mengetahui penurunan karakter-karakter tanaman akibat kondisi lingkungan yang sub-optimal dibandingkan dengan lingkungan optimumnya (Fisher dan Maurer, 1978). Semakin kecil nilai ISC, maka penurunan hasil tidak terlalu besar antara lingkungan suboptimal dan lingkungan optimal (Akbar et al., 2018).

Nilai indeks sensitivitas cekaman salinitas terhadap masing-masing peubah morfologi dan fisiologi disajikan pada Tabel 6. Pengelompokan tingkat sensitivitas tanaman terhadap salinitas dilakukan berdasarkan pengelompokan Fisher dan Maurer (1978), dimana jika nilai ISC $\leq 0.5$ maka genotipe tersebut toleran terhadap salinitas, jika $0.5<$ ISC $\leq 1.0$ maka genotipe tersebut medium (moderat) toleran terhadap salinitas, dan jika ISC $>1.0$ maka genotipe tersebut peka terhadap salinitas. Berdasarkan Tabel 6, dapat dilihat bahwa besarnya nilai rata-rata ISC pada genotipe Sigantung sebesar 1.2 dan CSR1 memiliki nilai sebesar 1.0. Berdasarkan nilai tersebut, yaitu ISC $>1.0$, maka Sigantung dan CSR1 termasuk katagori genotipe yang peka terhadap salinitas. Akan tetapi, genotipe CR10 dan CRK1 memiliki nilai rata-rata ISC sebesar 0.8 , sehingga termasuk ke dalam katagori moderat salinitas $(0.5<\mathrm{ISC}<0.1)$.

Tabel 6. Nilai indeks sensitivitas cekaman (ISC) empat genotipe cabai rawit terhadap peubah morfologi dan fisiologi yang diamati

\begin{tabular}{|c|c|c|c|c|c|c|c|c|c|c|c|c|c|c|c|}
\hline \multirow{2}{*}{ G } & \multicolumn{13}{|c|}{ Nilai ISC } & \multirow{2}{*}{$\mathrm{RC}$} & \multirow{2}{*}{ ST } \\
\hline & $\mathrm{PA}$ & TT & LT & $\mathrm{JD}$ & $\mathrm{JA}$ & $\mathrm{JU}$ & BB & $\mathrm{CO}$ & LF & LR & $\mathrm{KS}$ & KK & KR & & \\
\hline G3 & 1.0 & 1.2 & 0.6 & 1.8 & 2.5 & 1.2 & 1.2 & 3.3 & 0.5 & 0.6 & 0.7 & 0.5 & 0.5 & 1.2 & $\mathrm{P}$ \\
\hline G4 & 1.4 & 0.5 & 0.6 & 0.5 & 0.2 & 0.7 & 2.2 & 1.8 & 0.4 & 0.8 & 0.8 & 0.5 & 0.4 & 0.8 & $\mathrm{M}$ \\
\hline G5 & 1.0 & 0.5 & 0.3 & 2.8 & 1.0 & 0.7 & 1.6 & 2.5 & 0.4 & 0.6 & 0.6 & 0.4 & 0.3 & 1.0 & $\mathrm{P}$ \\
\hline G6 & 1.0 & 0.6 & 0.4 & 1.8 & 1.1 & 0.5 & 1.3 & 1.5 & 0.6 & 0.6 & 0.8 & 0.4 & 0.3 & 0.8 & $\mathrm{M}$ \\
\hline
\end{tabular}

Keterangan: $\mathrm{G}$ = genotipe; $\mathrm{G} 3$ = sigantung; $\mathrm{G} 4=\mathrm{CR} 10 ; \mathrm{G} 5=\mathrm{CSR}$; G6 = CRK1; PA = panjang akar; TT = tinggi tanaman; LT = lebar tajuk; JD = jumlah daun; $\mathrm{JA}=$ jumlah bunga; $\mathrm{JU}=$ jumlah bunga; $\mathrm{BB}=$ bobot buah; $\mathrm{CO}=$ konsentrasi $\mathrm{CO}_{2}$ intraseluler; $\mathrm{LF}=$ laju fotosintesis; $\mathrm{LR}=$ laju transpirasi; $\mathrm{KS}=$ konduktansi stomata; $\mathrm{KK}=$ indeks klorofil; $\mathrm{KR}=$ kadar air relatif; $\mathrm{RC}=$ rata-rata indeks sensitivitas cekaman, $\mathrm{ST}=$ status; $\mathrm{P}=$ peka; $\mathrm{M}=$ moderat

\section{KESIMPULAN}

Taraf salinitas $8-10 \mathrm{mS} \mathrm{cm}^{-1}$ menyebabkan penurunan hasil tertinggi pada peubah morfologi maupun fisiologi. Persentase penurunan hasil tertinggi (49\%-75\%) terdapat pada peubah jumlah bunga, jumlah daun, bobot buah, dan panjang akar. Selanjutnya, pada peubah fisiologi terjadi penurunan hasil tertinggi $(20 \%-30 \%)$ pada peubah konduktansi stomata, lebar tajuk, konsentrasi $\mathrm{CO}_{2}$ interseluler, dan indeks klorofil. Berdasarkan nilai rata-rata ISC, genotipe Sigantung (1.2) dan CSR1 (1.0) termasuk katagori peka terhadap salinitas (ISC >1.0). Akan tetapi, genotipe CR10 dan CRK1 memiliki nilai rata-rata ISC sebesar 0.8, sehingga termasuk ke dalam katagori moderat terhadap salinitas $(0.5<$ ISC $<0.1)$.

\section{UCAPAN TERIMA KASIH}

Terima kasih disampaikan kepada Kementerian Riset dan Teknologi yang telah membiayai penelitian ini melalui BPPTN 2019, dalam rangka kegiatan Penelitian Terapan Strategis Nasional.

\section{DAFTAR PUSTAKA}

Ahmed, H.A.A., N.K. Şahin, G. Akdoğan, C. Yaman, D. Köm, S. Uranbey. 2020. Variability in salinity stress tolerance of potato (Solanum tuberosum L.) varieties using in vitro screening. Cienc. e Agrotecnologia 44: $1-14$. 
Aini, N., Syekhfani, W.S.D. Yamika, P.R. Dyah, A. Setiawan. 2014. Growth and physiological characteristics of soybean genotypes (Glycine max L.) toward salinity stress. Agrivita. 36:201-209.

Akbar, M.R., B.S. Purwoko, I.S. Dewi, B. Suwarno. 2018. Penentuan indeks seleksi toleransi kekeringan galur dihaploid padi sawah tadah hujan pada fase perkecambahan. J. Agron. Indonesia 46:133-139.

Balasankar, D., S. Praneetha, T. Arumugam, N. Manivannan, P. Jeyakumar, K. Arulmozhiselvan. 2017. Assessment of salinity tolerance in chilli (Capsicum annuum L.) genotypes. IJCS. 5:1194-1198.

El-Hashash, E.F., A.M. Agwa. 2018. Genetic parameters and stress tolerance index for quantitative traits in barley under different drought stress severities. Asian J. Res. Crop Sci. 1:1-16.

Fisher, R.A., R. Maurer. 1978. Drought resistance in spring wheat cultivars. I. Grain yield. Aust. J. Agric. Res. 29:897-907.

Giorio, P., V. Cirillo, M. Caramante, M. Oliva, G. Guida, A. Venezia, S. Grillo, A. Maggio, R. Albrizio. 2020. Physiological basis of salt stress tolerance in a landrace and a commercial variety of sweet pepper (Capsicum annuum 1.). Plants 9:1-13.

[IPGRI] International Plant Genetic Resources Institute. 1995. Descriptor for Capsicum (Capsicum spp.). IPGRI, AVRDC, CATIE. Italy.

Julien, K.K., M.A. Abdou, C.G.M. Armel, A.K. Françoise, K. Eliane, L. Latifou, B. G. Christophe. 2019. Effect of salt stress on flowering, fructification and fruit nutrients concentration in a local cultivar of chili pepper (Capsicum frutescens L.). Int. J. Plant Physiol. Biochem. 11:1-7.

Kotagiri, D., V. Chaitanya. 2017. Effect of Salinity Stress on the Morphology and Physiology of Five Different Coleus Species. Biomed. Pharmacol. J. 10:16391649 .

Marohn, C., A. Distel, G. Dercon, Wahyunto, R. Tomlinson, M.V. Noordwijk, G. Cadisch. 2012. Impacts of soil and groundwater salinization on tree crop performance in post-tsunami Aceh Barat, Indonesia. Nat. Hazards Earth Syst. Sci. 12:2879-2891.
Martínez, J.P., R. Fuentes, K. Farías, C. Lizana, J.F. Alfaro, L. Fuentes, N. Calabrese, S. Bigot, M. Quinet, S. Lutts. 2020. Effects of salt stress on fruit antioxidant capacity of wild (Solanum chilense) and domesticated (Solanum lycopersicum var. cerasiforme) tomatoes. Agronomy 10:1481.

Muhni, A., M.S.D. Hadian, T.Y.W.M. Iskandarsyah, G.S. Nugraha. 2018. The susceptibility of seawater intrusion based on resistivity at Banda Aceh City, Indonesia. IOP Conf. Ser. Earth Environ. Sci. $145(1)$.

Mustafa, M., Y.F. Syahri, M. Rauf. 2019. Selection of chilli pepper (Capsicum frutescens L.) for salinity tolerance in seed germination. Agrotech J. 4:83-90.

Purnama, S. 2019. Groundwater vulnerability from sea water intrusion in coastal area Cilacap, Indonesia. Indones. J. Geogr. 51:206-216.

Putra, D.B.E., Y. Yuskar, H. Kausarian, W.Z. Wan Yaacob, M.S.D. Hadian. 2019. Saltwater intrusion zone mapping on shallow groundwater aquifer in Selat Baru, Bengkalis Island, Indonesia. J. Geosci. Eng. Environ. Technol. 4:16.

Qiu, R., Z. Yang, Y. Jing, C. Liu, X. Luo, Z. Wang. 2018. Effects of irrigation water salinity on the growth, gas exchange parameters, and ion concentration of hot pepper plants modified by leaching fractions. HortScience. 53:1050-1055.

Rachman, A., A. Dariah, S. Sutono. 2018. Pengelolaan Sawah Salin Berkadar Garam Tinggi. IAARD Press. Jakarta.

Ramli, M., Purwanto, A.V. Anas. 2019. Subsurface investigation of freshwater-seawater interface on Gowa-Takalar Coastal Aquifer, Indonesia. IOP Conf. Ser. Mater. Sci. Eng. 676(1).

Safi, A., G. Rachid, M. El-Fadel, J. Doummar, M. Abou Najm, I. Alameddine. 2018. Synergy of climate change and local pressures on saltwater intrusion in coastal urban areas: effective adaptation for policy planning. Water Int. 43:145-164.

Sembiring, H., N.A. Subekti, Erythrina, D. Nugraha, B. Priatmojo, A.M. Stuart. 2020. Yield gap management under seawater intrusion areas of Indonesia to improve rice productivity and resilience to climate change. Agric. 10:1-13. 
Smart, R.E., G.E. Bingham. 1974. Rapid Estimates of relative water content. Plant Physiol. 53:258-260.

Sobir, Miftahudin, S. Helmi. 2018. Respon morfologi dan fisiologi genotipe terung (Solanum melongena L.) terhadap cekaman salinitas. J. Hort. Indonesia 9: 131-138.

Sopandie, D. 2013. 2013. Fisiologi Adaptasi Tanaman terhadap Cekaman Abiotik pada Agroekosistem Tropika. IPB Pr. Bogor.
Suhartono, E., P. Purwanto, S. Suripin. 2015. Seawater intrusion modeling on ground water confined aquifer in Semarang. Procedia Environ. Sci. 23:110-115.

Tehseen, S., C.M. Ayyub, M. Amjad, R. Ahmad. 2016. Assessment of salinity tolerance in bell pepper (Capsicum annuum L.) genotypes on the basis of germination, emergence and growth attributes. Pak. J. Bot. 48:1783-1791. 